\title{
The homologies of gas vesicle proteins
}

\author{
AnN E. Griffiths, A. E. Walsby* and P. K. Hayes \\ Department of Botany, University of Bristol, Woodland Road, Bristol BS8 1UG, UK
}

(Received 19 November 1991; revised 29 January 1992; accepted 17 February 1992)

\begin{abstract}
In addition to GvpA, the main structural protein, an SDS-soluble protein has been found in gas vesicles isolated from six different genera of cyanobacteria. $\mathrm{N}$-terminal sequence analysis of the first 30 to 60 residues of the gelpurified proteins showed that they were homologous to $\mathrm{GvpC}$, a protein that strengthens the gas vesicle in Anabaena flos-aquae. The proteins from some of the organisms showed rather low homology, however, and this may explain why the genes that encode them have not been found by Southern hybridization studies. The gas vesicles of another cyanobacterium, Dactylococcopsis salina, contained two SDS-soluble proteins $\left(M_{\mathrm{r}} 17000\right.$ and 35000 ) that were identical in sequence for the first 24 residues but not thereafter; these two proteins showed no clear homology to GvpC. The sequence of GvpA, the main structural gas vesicle protein, was very similar in each of the organisms investigated. GvpA from the purple bacterium Amoebobacter pendens was different for the first 8 residues but 51 of the next 56 residues were identical to those of the cyanobacterial GvpA. Analysis of the GvpA and GvpC sequences provides support for the idea that the low diversity of GvpA reflects a high degree of conservation rather than a recent origin followed by lateral gene transfer between different bacteria.
\end{abstract}

\section{Introduction}

Gas vesicles provide many micro-organisms with buoyancy. They occur in at least five of the eleven phyla in the Bacteria (the cyanobacteria, green sulphur bacteria, green non-sulphur bacteria, purple bacteria and Grampositive bacteria), and two of the phyla in the Archaea sensu Woese et al. (1990) (the extreme halophiles and methanogens). In cyanobacteria the gas vesicle has the form of a hollow cylindrical tube closed by hollow conical end caps (Bowen \& Jensen, 1965; Jost, 1965). Both the end caps and the central cylinder are made up of ribs $4.6 \mathrm{~nm}$ wide, which, in gas vesicles of Anabaena flosaquae, have a crystallographic structure with subunits repeating at intervals of $1.15 \mathrm{~nm}$ (Blaurock \& Walsby, 1976). Direct amino acid sequencing has shown that these gas vesicles contain a small, mainly hydrophobic protein of 70 amino acid residues, which corresponds in size to that of the crystallographic unit cell (Walker et al., 1984; Hayes et al., 1986). Similar proteins have been demonstrated in gas vesicles of five other genera of cyanobacteria (Walker et al., 1984; Hayes et al., 1986), and two species of halobacteria (Walker et al., 1984; Surek et al., 1988).

Tandeau de Marsac et al. (1985) isolated the gene $(g v p A)$ that encodes this protein, which is now termed

\footnotetext{
* Author for correspondence. Tel. (0272) 303761.
}

GvpA, from Calothrix sp. PCC 7601. Downstream from gvp $A$ was a second gene that encoded an identical protein and an open reading frame, $g v p C$, encoding a putative protein of 162 amino acids that had four contiguous repeats of 33 amino acid residues (Damerval et al., 1987).

Damerval et al. (1989) showed by Southern hybridization that of 24 gas-vacuolate strains of cyanobacteria all contained a gene homologous to gvpA from Calothrix sp. but only 12 contained sequences homologous to $g v p C$ from the same organism. They concluded that either the product of $g v p C$ was not essential for gas vesicle formation, or the gene had diverged to the extent that it could no longer be detected by DNA:DNA hybridization.

Hayes et al. (1988) isolated a gene homologous with the Calothrix gvpC from Anabaena flos-aquae and showed that its product, the protein $\mathrm{GvpC}$, was a component of the gas vesicle. GvpC accounted for only $2.9 \%$ of the protein molecules present in the structure, with GvpA making up the remainder (Walsby \& Hayes, 1988; Hayes et al., 1988). Walsby \& Hayes (1988) showed that the GvpC could be removed from the gas vesicle by rinsing with detergent; the structure remained intact but was weakened. It was concluded that GvpC was located on the outside of the gas vesicle and it was suggested that its function might be to strengthen the ribbed structure formed by GvpA. This was confirmed by Hayes et al. (1992), who demonstrated that GvpC could be 
reattached to gas vesicles that had been stripped of their native $\mathrm{GvpC}$, and that this restored their strength.

The fact that the basic gas-filled structure of the gas vesicle survives when GvpC is removed may indicate that this protein is not absolutely essential for its formation. We have analysed the proteins in gas vesicles isolated from a number of cyanobacteria to determine whether the GvpC-like proteins were universal constituents of these structures. We investigated representatives of three of the five taxonomic sections (I, III and IV) described by Rippka et al. (1979). Some Section V organisms (branched filaments) may produce gasvacuolate hormogonia but are not available in culture; no gas-vacuolate organisms are known from Section II.

\section{Methods}

Organisms and culture conditions. Gas vesicles were isolated from the bacteria listed in Table 1, which gives information on the taxonomic groupings and strain numbers from the following collections: Culture Collection of Algae and Protozoa (CCAP) at the Institute of Freshwater Ecology, Ambleside, Cumbria, UK; Pasteur Culture Collection (PCC), Institut Pasteur, Paris, France; Culture Collection of Algae (CYA) at the Norwegian Institute for Water Research, Oslo, Norway. Anabaena flos-aquae was grown in the medium of Walsby \& Booker (1980). Aphanizomenon flos-aquae and Calothrix sp. were grown in medium B + N of Armstrong et al. (1983). Dactylococcopsis salina was grown at $32{ }^{\circ} \mathrm{C}$ in the medium described by Walsby et al. (1983), but with lower concentrations of $\mathrm{CaCl}_{2} .2 \mathrm{H}_{2} \mathrm{O}\left(0.08 \mathrm{~g} \mathrm{l}^{-1}\right), \mathrm{K}_{2} \mathrm{HPO}_{4}$ $\left(8 \mathrm{mg} \mathrm{1}^{-1}\right)$ and $\mathrm{Na}_{2} \mathrm{CO}_{3}\left(2 \mathrm{mg} \mathrm{l}^{-1}\right)$, and a higher concentration of $\mathrm{Na}_{2}$ EDTA ( $\left.3 \mathrm{mg}^{-1}\right)$. Microcystis $\mathrm{sp}$. was grown in medium BG 11 of Rippka et al. (1979). The green strain of Oscillatoria agardhii was grown in the medium of Van Liere \& Mur (1978). Spirulina sp. was grown in medium containing the following ingredients in 1 litre: $\mathrm{NaCl}(1 \mathrm{~g})$,
$\mathrm{NaNO}_{3}(2.5 \mathrm{~g}), \mathrm{CaCl}_{2}(0.04 \mathrm{~g}), \mathrm{FeSO}_{4} .7 \mathrm{H}_{2} \mathrm{O}(0.01 \mathrm{~g}), \mathrm{Na}_{2} \mathrm{EDTA}$ $(0.08 \mathrm{~g}), \mathrm{K}_{2} \mathrm{SO}_{4}(1 \mathrm{~g}), \mathrm{MgSO}_{4} .7 \mathrm{H}_{2} \mathrm{O}(0.2 \mathrm{~g}), \mathrm{K}_{2} \mathrm{HPO}_{4}(0.5 \mathrm{~g}), \mathrm{NaHCO}_{3}$ $(16.8 \mathrm{~g})$, and $1 \mathrm{ml}$ of the trace element mixture of Stanier $e t$ al. (1971). All cultures were grown under warm white fluorescent light and bubbled continuously with air. Cells of Amoebobacter pendens were supplied by Professor Norbert Pfennig at the University of Konstanz, Germany.

Gas vesicle isolation. Cultures were left to stand at low irradiance $\left(<4 \mu \mathrm{mol} \mathrm{m} \mathrm{m}^{-2} \mathrm{~s}^{-1}\right)$ for up to $72 \mathrm{~h}$. Floating cells or filaments were drawn off from the liquid surface using a cannula attached to an evacuating Buchner flask. Cells of Aphanizomenon flos-aquae and Anabaena flosaquae were lysed by the addition of $0.7 \mathrm{M}$-sucrose, and incubated at $37^{\circ} \mathrm{C}$ for $2 \mathrm{~h}$. Cells of Amoebobacter pendens, Microcystis sp., Oscillatoria agardhii CYA 29 and Spirulina sp. were lysed by the addition of lysozyme (at concentrations of $0.75,4,4$ and $5 \mathrm{mg} \mathrm{ml}^{-1}$,

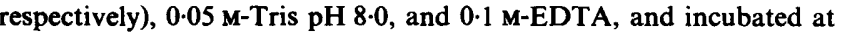
$37^{\circ} \mathrm{C}$ overnight. Cells of Dactylococcopsis salina were lysed by the addition of $4 \mathrm{mg}$ lysozyme $\mathrm{ml}^{-1}$ in $3 \%(\mathrm{w} / \mathrm{v}) \mathrm{NaCl}$, and $2 \%(\mathrm{v} / \mathrm{v})$ Triton $\mathrm{X}-100$. Lysis was confirmed under the light microscope. Gas vesicles were collected by accelerated flotation (Walsby, 1974). After three successive centrifugations, gas vesicles were filtered through $1.0 \mu \mathrm{m}$ pore size Nuclepore filters, concentrated as described above, and then stored at $4{ }^{\circ} \mathrm{C}$ in $0.05 \%(\mathrm{w} / \mathrm{v})$ ammonium bicarbonate solution (or $3 \%$, $\mathrm{w} / \mathrm{v}, \mathrm{NaCl}$ for Dactylococcopsis salina) containing $5 \mathrm{mM}-\mathrm{NaCN}$ to act as a preservative (Powell et al., 1991).

Electrophoretic purification of gas vesicle proteins. Collapsed gas vesicles were resuspended in $2.5 \%$ (w/v) SDS, $0.05 \%$ (w/v) bromophenol blue and $0.05 \%(\mathrm{w} / \mathrm{v})$ xylene Cyanol ff, and loaded into wells of $15 \%(\mathrm{w} / \mathrm{v})$ polyacrylamide gels (Laemmli, 1970). Protein bands were stained with Coomassie blue. The size of the protein in each band was estimated by comparison with proteins of known $M_{\mathrm{r}}$ (Rainbow, Amersham).

For sequencing studies, gels were lightly stained $(1 \mathrm{~min})$ and the required bands were cut out and eluted in $30 \mathrm{~mm}-$ Tris ( $\mathrm{pH} 8.5), 0.5 \mathrm{~mm}-$ EDTA, 1 mM-sodium thioglycollate and $0.1 \%$ (w/v) SDS. A current of 8-10 mA per tube was applied over $15 \mathrm{~h}$ (BioRad MiniProtean II Electro-eluter module). N-terminal amino acid sequences were obtained using an Applied Biosystems 477A protein sequencer.

Table 1. Soluble proteins in gas vesicles isolated from cyanobacteria and a purple bacterium

\begin{tabular}{|c|c|c|c|c|}
\hline Organism & Strain & Section* & $\begin{array}{c}\text { Estimated } \\
M_{\mathrm{r}} \dagger\end{array}$ & Reference to strain \\
\hline Anabaena flos-aquae & CCAP $1403 / 13 \mathrm{f}$ & IV & $28400 \ddagger$ & Walsby \& Hayes (1988) \\
\hline Aphanizomenon flos-aquae & CCAP 1401/1 & IV & 29700 & Walker et al. (1984) \\
\hline Calothrix sp. & PCC 7601 & IV & $20000 \S$ & Damerval et al. (1987) \\
\hline Dactylococcopsis salina & $\begin{array}{l}\text { PCC } 8305 \\
\text { CCAP } 1417 / 1\end{array}$ & I & $\begin{array}{l}35200 \\
17300\end{array}$ & Walker et al. (1984) \\
\hline Microcystis sp. & CCAP $1450 / 13$ & I & $25200 \ddagger$ & Walsby \& Hayes (1988) \\
\hline Oscillatoria agardhii (green) & $\begin{array}{l}\text { CYA } 29 \\
\text { CCAP } 1459 / 36\end{array}$ & III & 21700 & Walsby \& Bleything (1988) \\
\hline Spirulina sp. & CCAP $1475 / 10$ & III & 22100 & P. Newton (unpublished) \\
\hline Amoebobacter pendens & Konstanz 5813 & - & ND & Eichler \& Pfennig (1986) \\
\hline
\end{tabular}

* The systematic sections of cyanobacteria defined by Rippka et al. (1979).

† The $M_{\mathrm{r}}$ values estimated from the mobilities of bands in the SDS-PAGE system used. The discrepancies with the known values $(\ddagger, \S)$ indicate that the value given for other species may also be overestimated. ND, Not determined.

¥ The $M_{\mathrm{r}}$ indicated by the deduced amino acid sequence (Hayes et al., 1988) is 21985.

$\S$ The $M_{\mathrm{r}}$ indicated by the deduced amino acid sequence (Damerval et al., 1987), including $\mathrm{N}$-terminal Met, is 19179. 


\section{Results}

Electrophoretic separation of gas vesicle proteins

When entire gas vesicles from each of the cyanobacteria were analysed by SDS-PAGE, Coomassie blue stained three components: (1) the residual protein that failed to penetrate the gel, (2) a minor component that lodged at the junction of the stacking and separating gels, and (3) usually a single band in the separating gel with a mobility indicating an $M_{\mathrm{r}}$ in the range of 19000 to 30000 (Fig. 1). Previous studies on gas vesicles from Anabaena flosaquae showed that the protein in the well was GvpA and the protein in the mobile band was GvpC (Hayes et al., 1988; Walsby \& Hayes, 1989). Western blotting studies previously suggested that the protein at the top of the separating gel was GvpA (Walsby \& Hayes, 1989). To obtain confirmation of this, entire gas vesicles isolated from Anabaena flos-aquae were run on SDS-polyacrylamide gels, and the protein lodged at the top of the separating gel was eluted and sequenced. The sequence obtained was Ala-Val-Glu-Lys-Thr-Asn-Ser-Ser-Ser-SerLeu-Ala, which is the $\mathrm{N}$-terminal sequence of GvpA from Anabaena flos-aquae (Walker et al., 1984, and see Fig. 2). In similar gels that had been stained for a longer time it was possible to see, by examination with a hand lens, that this band comprised a family of very narrow

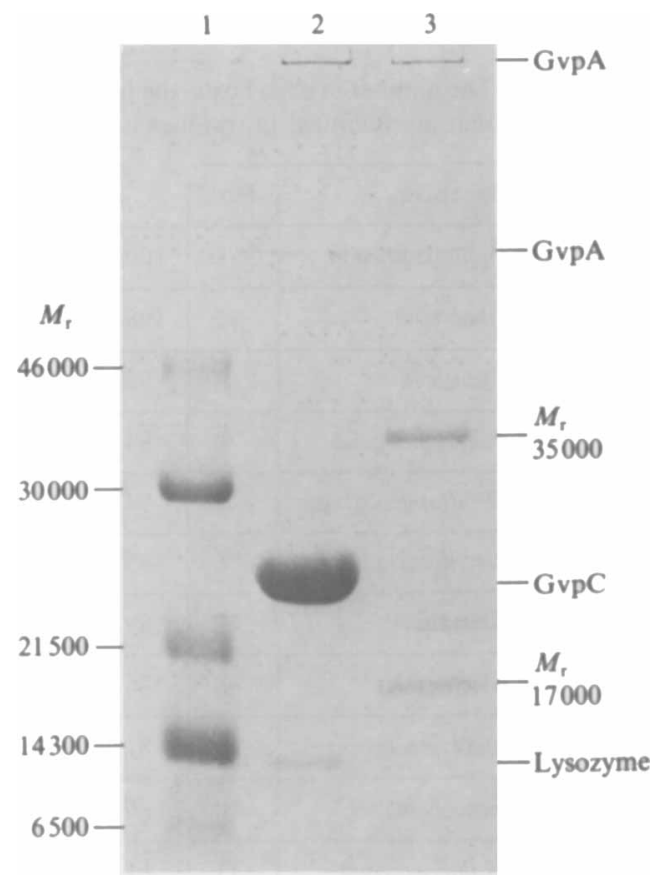

Fig. 1. SDS-polyacrylamide gel of proteins from isolated gas vesicles: lane 1 'Rainbow' size markers with $M_{\mathrm{r}}$ values; lane 2 Microcystis sp. showing, from the top, GvpA in the well, GvpA at the top of the running gel, GvpC, and a trace of lysozyme; lane 3, Dactylococcopsis salina showing two mobile bands.

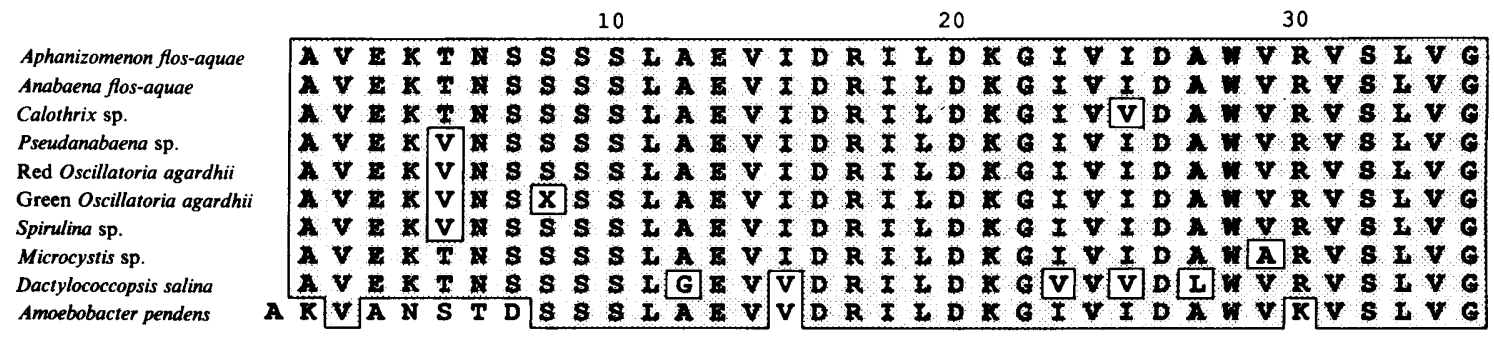

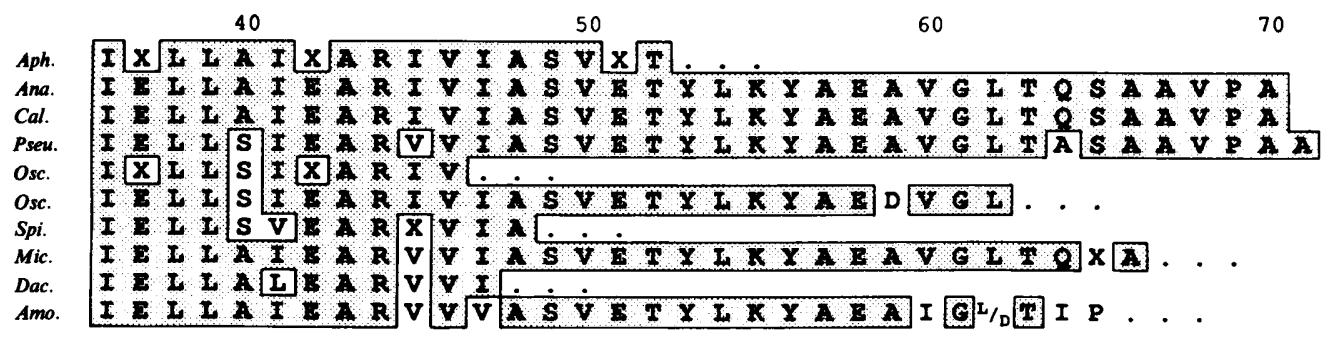

Fig. 2. Amino acid sequences for GvpA aligned to show the high degree of sequence homology within this family of proteins. Boxed and shaded areas show where the amino acid residues are identical for $50 \%$ or more of the proteins. Sequences for Anabaena flos-aquae, Calothrix sp. (PCC 7601) and Pseudanabaena sp. (PCC 6901) have been derived from their gene sequences (P. K. Hayes, unpublished; Tandeau de Marsac et al., 1985; Damerval et al., 1991). Partial amino acid sequences for Aphanizomenon flos-aquae, the red Oscillatoria agardhii CYA 18 (PCC 7821; CCAP 1459/37) and Microcystis sp. are from Walker et al. (1984) and Hayes et al. (1986). Residues of uncertain identity at positions 37 and 42 in the Aphanizomenon and red Oscillatoria sequences have been previously listed as P or P/E (Walker et al., 1984). (See Table 1 for other strain numbers). 
Table 2. Distance matrix analysis of GvpA sequence

The number in each box is the percentage of amino acid residues in the shorter sequence of each comparison that are identical to residues in the other sequence. For strain numbers see Table 1 and Fig. 1.

\begin{tabular}{|c|c|c|c|c|c|c|c|c|c|c|c|c|}
\hline Organism & No. & & & & & & & & & & & \\
\hline Aphanizomenon & 1 & 100 & & & & & & & & & & \\
\hline Anabaena & 2 & 100 & 100 & & & & & & & & & \\
\hline Calothrix & 3 & 98 & 99 & 100 & & & & & & & & \\
\hline Pseudanabaena & 4 & 94 & 94 & 93 & 100 & & & & & & & \\
\hline Oscillatoria green & 5 & 94 & 95 & 93 & 97 & 100 & & & & & & \\
\hline Oscillatoria red & 6 & 95 & 95 & 93 & 98 & 98 & 100 & & & & & \\
\hline Spirulina & 7 & 89 & 94 & 91 & 98 & 96 & 95 & 100 & & & & \\
\hline Microcystis & 8 & 96 & 97 & 95 & 94 & 92 & 91 & 91 & 100 & & & \\
\hline Dactylococcopsis & 9 & 81 & 85 & 87 & 83 & 79 & 80 & 81 & 85 & 100 & & \\
\hline Amoebobacter & 10 & 80 & 78 & 77 & 78 & 77 & 77 & 77 & 78 & 72 & 100 & \\
\hline Halobacterium & 11 & 61 & 55 & 57 & 54 & 57 & 59 & 64 & 60 & 64 & 58 & 100 \\
\hline Organism & No. & 1 & 2 & 3 & 4 & 5 & 6 & 7 & 8 & 9 & 10 & 11 \\
\hline
\end{tabular}

bands whose intensity decreased with distance from junction of the gels.

\section{$N$-terminal amino acid analysis of three new GvpAs}

The N-terminal amino acid sequences of GvpA, obtained by analysing entire gas vesicles, of the greencoloured strain of Oscillatoria agardhii CYA 29, Spirulina sp. and Amoebobacter pendens are shown in Fig. 2. Comparisons are made to sequences of GvpA in Anabaena flos-aquae, and other cyanobacteria previously investigated (Walker et al., 1984; Tandeau de Marsac et al., 1985; Hayes et al., 1986; Damerval et al., 1991) using distance matrix analysis (Table 2 ).

\section{The SDS-soluble gas vesicle proteins}

Gas vesicle proteins of Aphanizomenon flos-aquae, $\mathrm{Ca}$ lothrix sp., the green Oscillatoria agardhii, Spirulina sp. and Microcystis sp. were separated by SDS-PAGE. In each organism, a protein of $M_{\mathrm{r}}$ between 19000 and 30000 was observed (see Table 1).

Previous studies on Dactylococcopsis salina gas vesicles indicated only a single mobile band when gas vesicles were separated by SDS-PAGE (Hayes et al., 1986). In this study, however, two mobile bands were consistently found, one of $M_{\mathrm{r}} 35000$ as previously seen, and a second of $M_{\mathrm{r}} 17000$. The two bands were obtained even after rinsing the isolated gas vesicles with $2 \%(\mathrm{v} / \mathrm{v})$ Triton $\mathrm{X}-100,0.001 \%(\mathrm{w} / \mathrm{v}) \mathrm{SDS}$, and vigorous vortex-mixing in water. They were present in approximately equimolar quantities.

\section{Contamination by lysozyme}

In some of the samples (Microcystis, Spirulina, Oscillatoria, Amoebobacter) there was an additional minor band with a mobility indicating a $M_{\mathrm{r}}$ of about 14000 , which ran coincidentally with lysozyme. This band was gelpurified from a sample of Amoebobacter gas vesicles; Nterminal sequence analysis gave the amino acid sequence Lys-Val-Phe-Gly-Arg-(unknown)-Glu-Leu-Ala-Ala-AlaMet-Lys-Arg-His-Gly-Leu-Asp-Asn-Tyr-Arg-Gly-TyrSer-Leu-Gly-Asn, which identified this protein as lysozyme (Jung et al., 1980). It appeared that the lysozyme originally added to lyse the cells of these organisms had become adsorbed to the gas vesicles during the isolation procedure.

\section{$N$-terminal amino acid analysis of the GvpC-like proteins}

$\mathrm{N}$-terminal amino acid sequences obtained from the proteins eluted from the single mobile bands from Aphanizomenon flos-aquae, Oscillatoria agardhii CYA 29, Spirulina sp., and Microcystis sp., and the two mobile bands from Dactylococcopsis salina, are shown in Fig. 3. 
Aphanizomenon flos-aquae Anabaena flos-aquae Calothrix sp. Microcystis sp. Green Oscillatoria agardhii Spirulina sp. Dactylococcopsis salina

$17 \mathrm{kDa}$ $35 \mathrm{kDa}$
10

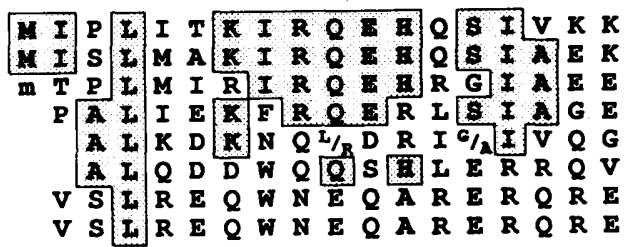

Aph.

Ana.

Cal.

Mic.

Osc.

Spi.

Dac. $\quad 17 \mathrm{kDa}$

$35 \mathrm{kDa}$

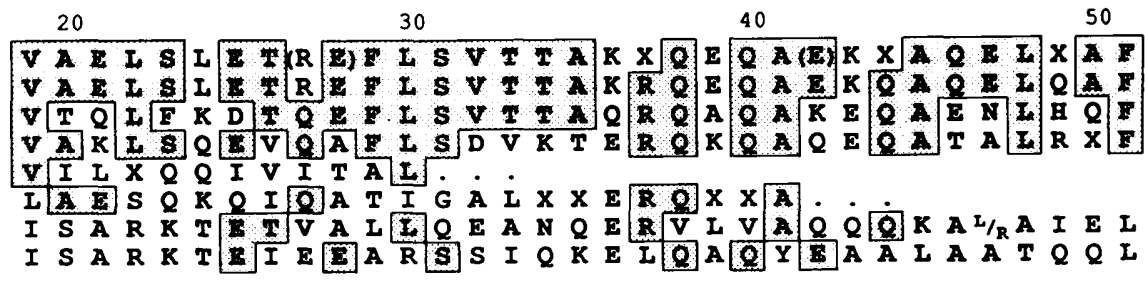$$
52
$$$$
\text { Y K }
$$

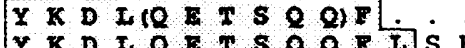

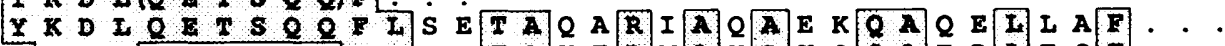

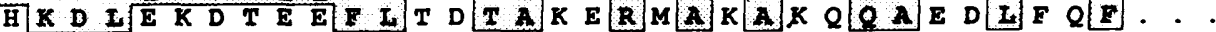
$\mathbf{F}$ L $\mathbf{Q}$. . .

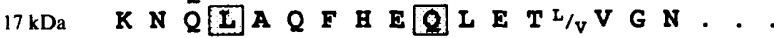

$35 \mathrm{kDa} \quad \mathrm{Q}^{\mathrm{S} / \mathrm{Q} / \mathrm{A}} \mathrm{X} \times \mathrm{R}$ E X R F Y . .

Fig. 3. Amino acid sequences for SDS-soluble proteins gel-purified from samples of gas vesicles. Boxed areas show where the amino acid residues are identical for $50 \%$ or more of the proteins, excluding the two Dactylococcopsis sequences. Sequences for Anabaena flosaquae and Calothrix sp. were derived from their gvpC sequences (Damerval et al., 1987; Hayes et al., 1988).

\section{Table 3. Distance matrix analysis of GvpC-like proteins}

The first number in each box is the percentage of amino acid residues in the shorter sequence of each comparison that are identical to residues in the other sequence, and the second number (in italics) is the percentage of residues that are similar. Similar residues are as defined by Devereux et al. (1984): neutral, weakly hydrophobic (P, A, G, S, T); hydrophilic, acid amine $(\mathrm{Q}, \mathrm{N}, \mathrm{E}, \mathrm{D})$; hydrophilic, basic $(\mathrm{H}, \mathrm{K}, \mathrm{R})$; hydrophobic (L, I, V, M); hydrophobic, aromatic (F, Y, W). For strain numbers see Table 1 and Fig. 1.

\begin{tabular}{|c|c|c|c|c|c|c|c|c|c|c|}
\hline Organism & No. & & & & & & & & & \\
\hline Aphanizomenon & 1 & $\begin{array}{l}100 \\
100\end{array}$ & & & & & & & & \\
\hline Anabaena & 2 & $\begin{array}{l}92 \\
97\end{array}$ & $\begin{array}{l}100 \\
100\end{array}$ & & & & & & & \\
\hline Calothrix & 3 & $\begin{array}{l}51 \\
71\end{array}$ & $\begin{array}{l}54 \\
73\end{array}$ & $\begin{array}{l}100 \\
100\end{array}$ & & & & & & \\
\hline Microcystis & 4 & $\begin{array}{l}42 \\
55\end{array}$ & $\begin{array}{l}45 \\
60\end{array}$ & $\begin{array}{l}42 \\
66\end{array}$ & $\begin{array}{l}100 \\
100\end{array}$ & & & & & \\
\hline Oscillatoria green & 5 & $\begin{array}{l}24 \\
36\end{array}$ & $\begin{array}{l}20 \\
36\end{array}$ & $\begin{array}{l}16 \\
36\end{array}$ & $\begin{array}{l}36 \\
52\end{array}$ & $\begin{array}{l}100 \\
100\end{array}$ & & & & \\
\hline Spirulina & 6 & $\begin{array}{l}20 \\
34\end{array}$ & $\begin{array}{l}23 \\
40\end{array}$ & $\begin{array}{l}23 \\
49\end{array}$ & $\begin{array}{l}31 \\
57\end{array}$ & $\begin{array}{l}24 \\
52\end{array}$ & $\begin{array}{l}100 \\
100\end{array}$ & & & \\
\hline Dactylococcopsis 17 & 7 & $\begin{array}{l}12 \\
32\end{array}$ & $\begin{array}{l}15 \\
35\end{array}$ & $\begin{array}{l}17 \\
38\end{array}$ & $\begin{array}{l}23 \\
42\end{array}$ & $\begin{array}{r}8 \\
40\end{array}$ & $\begin{array}{l}23 \\
49\end{array}$ & $\begin{array}{l}100 \\
100\end{array}$ & & \\
\hline Dactylococcopsis 35 & 8 & $\begin{array}{l}13 \\
27\end{array}$ & $\begin{array}{l}16 \\
27\end{array}$ & $\begin{array}{l}16 \\
34\end{array}$ & $\begin{array}{l}17 \\
38\end{array}$ & $\begin{array}{r}8 \\
36\end{array}$ & $\begin{array}{l}20 \\
57\end{array}$ & $\begin{array}{l}50 \\
57\end{array}$ & $\begin{array}{l}100 \\
100\end{array}$ & \\
\hline Halobacterium & 9 & $\begin{array}{r}5 \\
24\end{array}$ & $\begin{array}{r}5 \\
28\end{array}$ & $\begin{array}{r}8 \\
19\end{array}$ & $\begin{array}{r}8 \\
15\end{array}$ & $\begin{array}{r}0 \\
19\end{array}$ & $\begin{array}{r}9 \\
29\end{array}$ & $\begin{array}{r}9 \\
20\end{array}$ & $\begin{array}{r}5 \\
17\end{array}$ & $\begin{array}{l}100 \\
100\end{array}$ \\
\hline Organism & No. & 1 & 2 & 3 & 4 & 5 & 6 & 7 & 8 & 9 \\
\hline
\end{tabular}


Also shown are the $\mathrm{N}$-terminal portions of the deduced amino acid sequences of GvpC from Calothrix sp. and Anabaena flos-aquae which have been obtained from the gene sequences (Damerval et al., 1987; Hayes et al., 1988). The presence of GvpC in Anabaena flos-aquae gas vesicles was previously confirmed by $\mathrm{N}$-terminal sequencing of the gel-purified protein (Hayes et al., 1988), and in Calothrix by SDS-PAGE, which revealed a 20000 $M_{\mathrm{r}}$ band (Damerval et al., 1991), which is close to the $M_{\mathrm{r}}$ of the $g v p C$ gene product, 19179 (Damerval et al., 1987). The N-terminal sequences of these seven proteins are compared to one another by distance matrix analysis in Table 3.

\section{Discussion}

GvpA

Our results confirm the presence of two types of protein in the gas vesicles of Anabaena flos-aquae. The identification of the series of bands at the top of the stacking gel as GvpA indicates that this protein forms aggregates that are not easily disrupted. Walker \& Walsby (1983) found that the Anabaena gas vesicle membranes could be completely dissolved to form a clear solution in $80 \%$ (v/v) formic acid, but only the $M_{\mathrm{r}} 22000$ band, now known to be GvpC, was subsequently obtained by SDSPAGE. Damerval et al. (1991) showed that a single mobile band of $M_{\mathrm{r}} 7000$ could be obtained from gas vesicles of Pseudanabaena sp. PCC 6901 after dissolving them in formic acid; this is probably GvpA, but its identity should be confirmed by $\mathrm{N}$-terminal sequence analysis.

Our three new GvpA sequences provide further evidence of the high degree of conservation of this protein (Table 2). It is of interest that the sequences of the four Section III cyanobacteria - Pseudanabaena, Spirulina and the two Oscillatoria strains - are identical up to residue 40 , and are distinct from all of the others in having valine at residue 5 and serine at residue 40 .

The first eight residues of the Amoebobacter pendens GvpA differ from the cyanobacterial sequence but of the next 56 residues 51 are identical to the consensus sequence; the five changes are all conservative (four of them Ile $\rightarrow$ Val, and the fifth Arg $\rightarrow$ Lys) and two of them occur in other cyanobacteria. In fact this section shows more similarity to the consensus cyanobacterial sequence than the corresponding portion of Dactylococcopsis GvpA. The Amoebobacter GvpA shows greater homology to the cyanobacterial consensus sequence $(80 \%)$ than to the sequence of Halobacterium halobium GvpA (58\%).

Although gas vesicles of different cyanobacteria (and other organisms) are remarkably similar in overall shape and fine structure, they do differ in cylindrical diameter
(Hayes \& Walsby, 1986; Walsby \& Bleything, 1988). These differences in gas vesicle diameter could be determined by the amino acid sequence of GvpA or GvpC, or by other gene products that might be involved in assembly of the structure. Diameter is important because it determines the critical collapse pressure of the gas vesicle and its efficiency in providing buoyancy (Walsby \& Bleything, 1988).

\section{$G v p C$}

Preparations of gas vesicles isolated from seven genera of cyanobacteria have now been shown to contain SDSsoluble proteins. In four of these genera, Anabaena, Aphanizomenon, Calothrix and Microcystis, comparison of the sequences of these proteins indicates significant homology (Fig. 3, Table 3); in the other three genera the homology is less clear-cut.

Only $20 \%$ of the residues in the Oscillatoria protein are identical to those in the Anabaena GvpC, but $36 \%$ are identical to those in Microcystis GvpC. A number of the different residues indicate conservative changes; including these conservative changes yields $52 \%$ residues that are similar to those in Microcystis GvpC. For the Spirulina protein there are only $23 \%$ of residues identical to Anabaena GvpC and $31 \%$ to Microcystis GvpC, but the percentages of similar residues are $40 \%$ and $57 \%$, respectively. These comparisons suggest that the proteins of these two species are also part of the GvpC family. Further evidence that they are true components of the gas vesicle might be provided by showing that they can restore the strength of the gas vesicles on being readsorbed by them, or by showing that the encoding genes form part of a $g v p$ operon.

The two SDS-soluble proteins obtained from Dactylococcopsis salina gas vesicles show little homology with the other GvpCs and we have no direct evidence that these two proteins are the homologues or even the functional analogues of $\mathrm{GvpC}$. The remarkable feature of the two sequences is that the first 24 residues are identical; a gene duplication must have been responsible for this.

The results of this survey provide evidence that SDSsoluble outer-proteins are widespread, if not universally present, on the gas vesicles of cyanobacteria. Recent studies on the mechanical properties of gas vesicles (Walsby, 1991) indicate that GvpC increases the critical pressure of the structure by postponing buckling. This property would be especially important in wide gas vesicles, such as those of the halobacteria (Walsby, 1971). There is no direct information at present on whether halobacterium gas vesicles contain a functional analogue of GvpC, but in the gvp operon of Halobacterium halobium there is a gene downstream from gvp $A$ that encodes a protein which, like the cyanobacterial GvpCs, 
has a high content of acidic amino acids and a repeating structure, in this case seven repeats of length between 32 and 40 residues (Jones et al., 1991; Horne et al., 1991). The N-terminal sequence of this protein shows no homology to the cyanobacterial GvpCs (see Table 3) although the repeating sections show some weak homology with those in Calothrix GvpC (Jones et al., 1991). It is not known if it is this protein or GvpA that constitutes the mobile band when gas vesicle proteins of halobacteria are separated by electrophoresis (see Simon, 1981; Surek et al., 1988).

It remains now to question whether there are cases where gas vesicles lack GvpC. The observation (Damerval et al., 1989) that Southern hybridization fails to find homologues of the Calothrix gvpC gene in certain cyanobacteria could be accounted for by the low degree of conservation of the encoded proteins. This would explain, for example, why homologous genes were found in species of Anabaena and Microcystis, where there is distinct homology between the proteins, but not in species of Oscillatoria, where the homology is less. Damerval et al. (1991) found no evidence of GvpC in gas vesicles isolated from Pseudanabaena, however, and they found no $g v p C$-like gene immediately downstream of the single gvpA gene in this organism. It is possible, of course, that this outer protein could have been lost during the isolation procedure, and that the encoding gene could be located further away from $g v p A$. Nevertheless, there is no direct evidence of GvpC in the Pseudanabaena gas vesicles and as Damerval et al. (1991) have pointed out, they may derive their stability from their small dimensions. A direct investigation of the relationship between the diameter and critical pressure of the Pseudanabaena gas vesicle is now required, using the methods developed by Walsby \& Bleything (1988).

\section{Evolution of GvpA and GvpC}

Gas vesicles are found in two groups of micro-organisms, the Bacteria and Archaea, that diverged at an early stage of evolution (Woese, 1987; Woese et al., 1990). If gas vesicles existed before the divergence of these two groups, the high degree of homology between extant GvpAs would indicate that there had been a very low rate of mutation in the gvpA genes (Damerval et al., 1987). Alternatively, the gene may have developed more recently, mutated at a higher rate, and then become transferred laterally between the different organisms (Walker et al., 1984). The much smaller degree of homology of GvpC is consistent with a long evolution of its encoding gene. It is unlikely that GvpC predated GvpA, and we therefore favour the idea that both genes are ancient and that the slower mutation rate of GvpA must be due, at least in part, to this small protein having to fulfil a number of requirements to produce a gas-filled structure.

We are grateful to Professor Norbert Pfennig at the University of Konstanz, who supplied cells of Amoebobacter pendens, to Dr N. Avent, who provided advice on protein extraction, to $\mathrm{Dr}$ W. Mawby, who provided amino acid sequencing services at the Molecular Recognition Centre, in the Department of Biochemistry in the University of Bristol, and to $\mathrm{MrT}$. Colburn for drawing the figures. This work was supported by the provision of a grant and a research studentship by the SERC.

\section{References}

Armstrong, R. E., Hayes, P. K. \& Walsby, A. E. (1983). Gas vacuole formation in hormogonia of Nostoc muscorum. Journal of General Microbiology 128, 263-270.

Blaurock, A. E. \& Walsby, A. E. (1976). Crystalline structure of the gas vesicle wall from Anabaena flos-aquae. Journal of Molecular Biology 105, 183-199.

Bowen, C. C. \& JenSEN, T. E. (1965). Blue-green algae: fine structure of the gas vacuoles. Science 147, 1460-1462.

Damerval, T., Houmard, J., Guglielmi, G., Csiszàr, K. \& Tandeau DE MARSAC, N. (1987). A developmentally regulated gvpABC operon is involved in the formation of gas vesicles in the cyanobacterium Calothrix 7601. Gene 54, 83-92.

Damerval, T., Castets, A.-M., Guglielmi, G., Houmard, J. \& TANDEAU De MARSAC, N. (1989). Occurrence and distribution of gas vesicle genes among cyanobacteria. Journal of Bacteriology 171, 1445-1452.

Damerval, T., Castets, A.-M., Houmard, J. \& Tandeau de Marsac, N. (1991). Gas vesicle synthesis in the cyanobacterium Pseudanabaena sp.: occurrence of a single photoregulated gene. Molecular Microbiology 5, 657-664.

DevereuX, J., Haeberli, P. \& Smithies, O. (1984). A comprehensive set of sequence analysis programs for the VAX. Nucleic Acids Research 12, 387-395.

EICHLER, B. \& PFENNIG, N. (1986). Characterization of a new plateletforming purple sulfur bacterium, Amoebobacter pedioformis $\mathrm{sp}$. nov. Archives of Microbiology 146, 295-300.

HAYES, P. K. \& W ALSBY, A. E. (1986). The inverse correlation between width and strength of gas vesicles in cyanobacteria. British Phycological Journal 21, 191-197.

Hayes, P. K., Walsby, A. E. \& Walker, J. E. (1986). Complete amino acid sequence of cyanobacterial gas-vesicle protein indicates a 70 residue molecule that corresponds in size to the crystallographic unit cell. Biochemical Journal 236, 31-36.

Hayes, P. K., Lazarus, C. M., Bees, A., Walker, J. E. \& Walsby, A. E. (1988). The protein encoded by $g v p C$ is a minor component of gas vesicles isolated from the cyanobacteria Anabaena flos-aquae and Microcystis sp. Molecular Microbiology 2, 545-552.

Hayes, P. K., BuchHolz, B. \& WALsBY, A. E. (1992). Gas vesicles are strengthened by the outer-surface protein, GvpC. Archives of Microbiology (in the Press).

Horne, M., Englert, C., Wimmer, C. \& Pfeifer, F. (1991). A DNA region of $9 \mathrm{kbp}$ contains all genes necessary for gas vesicle synthesis in halophilic archaebacteria. Molecular Microbiology 5, 1159-1174.

Jones, J. G., Young, D. C. \& DasSarma, S. (1991). Structure and organization of the gas vesicle gene cluster on the Halobacterium halobium plasmid pNCR100. Gene 102, 117-122.

JosT, M. (1965). Die Ultrastruktur von Oscillatoria rubescens D.C. Archiv für Mikrobiologie 50, 211-245.

JUNG, A., SiPPEL, A. E., GrEZ, M. \& SCHUTZ, G. (1980). Exons encode functional and structural units of chicken lysozyme. Proceedings of the National Academy of Sciences of the United States of America 77, 5759-5763. 
LAEMmLI, U. K. (1970). Cleavage of structural proteins during the assembly of the head of bacteriophage T4. Nature, London 227, 680685.

Powell, R. S., Walsby, A. E., Hayes, P. K. \& Porter, R. (1991). Antibodies to the N-terminal sequence of GVPa bind to the ends of gas vesicles. Journal of General Microbiology 137, 2395-2400.

RipPKa, R., Deruelles, J., Waterbury, J. B., Herdman, M. \& STANIER, R. Y. (1979). Generic assignments, strain histories and properties of pure culture of cyanobacteria. Journal of General Microbiology 111, 1-61.

SimON, R. (1981). Morphology and protein composition of gas vesicles from wild type and gas vacuole deficient strains of Halobacterium halobium strain 5. Journal of General Microbiology 125, 103-111.

Stanier, R. Y., Kunisawa, R., Mandel, M. \& Cohen-Bazire, G. (1971). Purification and properties of unicellular blue-green algae (order Chroococcales). Bacteriological Reviews 35, 171-205.

Surek, B., Pillay, B., Rdest, U., Beyreuther, K. \& Goebel, W. (1988). Evidence for two different gas vesicle proteins and genes in Halobacterium halobium. Journal of Bacteriology 70, 1746-1751.

Tandeau de Marsac, N., Mazel, D., Bryant, D. A. \& Houmard, J. (1985). Molecular cloning and nucleotide sequence of a developmentally regulated gene from the cyanobacterium Calothrix PCC 7601: a gas vesicle protein gene. Nucleic Acids Research 13, 7223-7236.

VAN LiERE, L. \& MUR, L. (1978). Light-limited cultures of the bluegreen alga Oscillatoria agardhii. Mitteilungen der Internationalen Vereinigung für theoretische und angewandte Limnologie 21, 158-167.

WALKER, J. E. \& WALSBY, A. E. (1983). Molecular weight of gas-vesicle protein from the planktonic cyanobacterium Anabaena flos-aquae and implications for structure of the vesicle. Biochemical Journal 209 , 809-815.
WALKer, J. E., HAYES, P. K. \& WALSBY, A. E. (1984). Homology of gas vesicle proteins in cyanobacteria and halobacteria. Journal of General Microbiology 130, 2709-2715.

WALSBY, A. E. (1971). The pressure relationships of gas vacuoles. Proceedings of the Royal Society B178, 301-326.

WaLSBY, A. E. (1974). The isolation of gas vesicles from blue-green algae. Methods in Enzymology 31, 678-686.

WALSBY, A. E. (1991). The mechanical properties of the Microcystis gas vesicle. Journal of General Microbiology 137, 2401-2408.

WalsBy, A. E. \& BLEYTHING, A. (1988). The dimensions of cyanobacterial gas vesicles in relation to their efficiency in providing buoyancy and withstanding pressure. Journal of General Microbiology 134, 2635-2645.

WALSBY, A. E. \& Booker, M. J. (1980). Changes in buoyancy of a planktonic blue-green alga in response to light intensity. British Phycological Journal 15, 311-319.

WALSBY, A. E. \& HaYes, P. K. (1988). The minor cyanobacterial gas vesicle protein, GVPc, is attached to the outer surface of the gas vesicle. Journal of General Microbiology 134, 2647-2657.

WALSBY, A. E. \& HAYES, P. K. (1989). Gas vesicle proteins. Biochemical Journal 264, 313-322.

WalsbY, A. E., VAN RiJn, J. \& CohEN, Y. (1983). The biology of a new gas-vacuolate cyanobacterium, Dactylococcopsis salina sp. nov., in Solar Lake. Proceedings of the Royal Society of London B217, 417-447.

WoESE, C. R. (1987). Bacterial evolution. Microbiological Reviews 51, 221-271.

Woese, C. R., Kandler, O. \& Wheelis, M. L. (1990). Towards a natural system of organisms: proposal for the domains Archaea, Bacteria, and Eucarya. Proceedings of the National Academy of Sciences of the United States of America 87, 4576-4579. 